Article

\title{
Baccharis trimera (Less.) DC Exhibits an Anti-Adipogenic Effect by Inhibiting the Expression of Proteins Involved in Adipocyte Differentiation
}

\author{
Daniele de Souza Marinho do Nascimento ${ }^{1,2}$, Ruth Medeiros Oliveira ${ }^{2,3}$, \\ Rafael Barros Gomes Camara 2,4, Dayanne Lopes Gomes 1,2, Jessika Fernanda Santiago Monte 2, \\ Mariana Santana Santos Pereira Costa ${ }^{2,5}$, Júlia Moraes Fernandes ${ }^{6}$, \\ Silvana Maria Zucolotto Langassner 1,6 and Hugo Alexandre Oliveira Rocha ${ }^{1,2, *}$
}

1 Programa de Pós-graduação em Ciencias da Saúde, Centro de Ciências da Saúde, Universidade Federal do Rio Grande do Norte-UFRN, R. Gen. Gustavo Cordeiro de Farias, s/n, Natal-RN 59012-570, Brazil; danysmari@yahoo.com.br (D.d.S.M.d.N.); dayanne_gomes@hotmail.com (D.L.G.); szucolotto@hotmail.com (S.M.Z.L.)

2 Departamento de Bioquimica, Centro de Biociencias, Universidade Federal do Rio Grande do Norte-UFRN, Av. Salgado Filho 3000, Natal-RN 59078-970, Brazil; rmo_85@hotmail.com (R.M.O.); rafael_bgc@yahoo.com.br (R.B.G.C.); jessika.monte@gmail.com (J.F.S.M.); mariana.costa@ifrn.edu.br (M.S.S.P.C.)

3 Instituto Federal de Educação, Ciência a Tecnologia do Rio Grande do Norte (IFRN), Rodovia RN-288, s/n-Nova Caicó, Caicó-RN 59300-000, Brazil

4 Escola Multicampi de Ciências Médicas do Rio Grande do Norte-EMCM/RN, Universidade Federal do Rio Grande do Norte-UFRN, Av. Cel. Martiniano, 354, Caicó-RN 59300-000, Brazil

5 Instituto Federal de Educação, Ciência a Tecnologia do Rio Grande do Norte (IFRN), Rua das margaridas, 300-Conjunto COHAB, Macau-RN 59500-000, Brazil

6 Departamento de Farmácia, Centro de Ciências da Saúde, Universidade Federal do Rio Grande do Norte-UFRN, Rua General Gustavo Cordeiro de Farias, s/n, Natal-RN 59012-570, Brazil; fernandesjm@outlook.com

* Correspondence: hugo@cb.ufrn.br; Tel.: +55-84-3215-3416

Academic Editor: Solomon Habtemariam

Received: 17 March 2017; Accepted: 7 June 2017; Published: 12 June 2017

\begin{abstract}
Baccharis trimera (Less.) DC (gorse) is a plant popularly used for the treatment of obesity. In this study, we prepared three $B$. trimera extracts aqueous extract (AE), decoction (AE-D), and methanol extract (ME) and investigated their antioxidant effects in six different tests and their anti-adipogenic effect in 3T3-L1 cells. The extracts showed a dose-dependent antioxidant activity in all tests. AE was the most potent antioxidant in copper and ferric ion chelation assays, whereas AE-D was the most potent in superoxide and hydroxyl radical scavenging assays, reducing power assay, and total antioxidant capacity analysis. Only ME showed a cytotoxic effect against 3T3-L1 cells. Lipid accumulation decreased in 3T3-L1 adipocytes in the presence of AE and AE-D extracts ( 0.5 to $1.0 \mathrm{mg} / \mathrm{mL}$ ). In addition, the extracts dramatically attenuated the levels of adipogenic transcriptional factors, including CCAAT enhancer-binding protein $\alpha(\mathrm{C} / \mathrm{EBP} \alpha)$, CCAAT enhancer-binding protein $\beta(C / E B P \beta)$, and gamma receptors by peroxisome proliferators (PPAR $\gamma)$, during adipogenesis. AE-D $(1.0 \mathrm{mg} / \mathrm{mL})$ caused an approximately $90 \%$ reduction in the levels of these molecules. We propose that $B$. trimera has an anti-adipogenic effect and could be used in the development of functional foods.
\end{abstract}

Keywords: adipogenesis; antioxidant; chlorogenic acid 


\section{Introduction}

Obesity is considered an important health issue since it is a risk factor for the development of a number of chronic diseases such as cardiovascular disease (primarily heart disease and stroke), diabetes, skeletal muscle disorders, and some cancers such as endometrial, breast, and colon [1]. Human obesity is defined as a BMI (body mass index) equal to or greater than $30 \mathrm{~kg} / \mathrm{m}^{2}$. A person with a BMI of 25 and $30 \mathrm{~kg} / \mathrm{m}^{2}$ is considered overweight. Moreover, according to the World Health Organization, between 1980 and 2014, the obesity index worldwide more than doubled. Worldwide, in 2014, approximately 39\% of adults (aged 18 years or older) were overweight and about $13 \%$ of the adult population was obese [1].

The development of adipose tissue involves both hyperplasia (increased number of cells) and hypertrophy (increase in cell size). Hyperplasia is related to the proliferation and differentiation of pre-adipocytes (adipogenesis), while hypertrophy is the result of an excessive accumulation of triglycerides in existing adipocytes [2].

Much of the knowledge about the molecular mechanisms and signals involved in adipogenesis was acquired through studies using the 3T3-L1 cell line [3]. The differentiation of these cells comprises precisely controlled sequential stages that include cell cycle arrest and clonal expansion and differentiation (first and second stages of transcription factor activation phase) through the activation of hundreds of previously silenced genes [4]. The exposure of confluent pre-cultured adipocytes (3T3-L1) to differentiation inducers leads to early events represented by the expression of CCAAT enhancer-binding proteins (C/EBPs), $\mathrm{C} / \mathrm{EBP}-\beta$, and C/EBP- $\delta[4,5]$. Subsequently, the cells resume their cell cycle, undergo clonal expansion, and enter a terminal differentiation process through the activation of gamma receptors by peroxisome proliferators (PPAR $\gamma$ ) and C/EBP- $\alpha$, both key regulators in the adipogenic process [5].

Few drugs have been approved by the U.S. Food and Drug Administration (FDA) for the treatment of obesity, and use of these has been associated with the onset of side effects, including the development of cardiovascular diseases [6]. Therefore, studies in various parts of the world have focused on the discovery of new sources that have anti-obesity and anti-adipogenic properties.

Several oxidants, such as hydrogen peroxide, are involved in the development of obesity. These oxidants act as signaling messengers inducing phosphorylation, oxidation, and dimerization related to the expression of C/EBP- $\alpha$ and PPAR $\gamma$ [7]. Thus, several compounds have anti-adipogenic activity because they prevent the increase in oxidant levels [8].

Baccharis trimera (Less.) DC is traditionally known in Brazil as "carqueja" and all parts of the plant are popularly used to produce a tonic that is consumed for body weight loss [9].

The antimicrobial [10], anti-inflammatory, analgesic [11], and hypoglycemic [12] effects of $B$. trimera have been reported. In addition, high-fat diet-induced obese rats showed both decreased weight and less serum cholesterol after treatment with the methanol extract of $B$. trimera than did the rats that did not receive the $B$. trimera extract [13]. Corroborating these findings, in vitro tests showed that $B$. trimera methanol extract inhibits pancreatic lipase and $\alpha$ - and $\beta$-glucosidases [14] whereas $B$. trimera aqueous extract inhibits only glucosidases [15]. B. trimera aqueous extract also showed antioxidant activity in the DPPH test [16] and the total radical-trapping antioxidant parameter (TRAP) test [17] but there are no data on $B$. trimera aqueous extract evaluations using other antioxidant tests. Moreover, there are no data about the anti-adipogenic effect of $B$. trimera. Thus, this study was performed to examine the antioxidant activity of $B$. trimera extract, as well as the effect of $B$. trimera extracts on adipogenic differentiation of 3T3-L1 cells.

\section{Results}

\subsection{Antioxidant Tests}

We tested the aqueous extract (AE), methanolic extract (ME) and decoction (AE-D) of B. trimera for antioxidant activity. The decoction, which is subsequently used to produce a tonic, is the version most commonly used as a folk remedy, and, for this reason, we investigated its antioxidant properties. 
As shown in Figure 1A, AE was the least effective extract, with an antioxidant activity that corresponds to $25.2 \mathrm{mg}$ of ascorbic acid equivalent, while AE-D and ME exhibited 35.1 and $33.0 \mathrm{mg}$ of ascorbic acid equivalent, respectively.

The reducing power assay was used to assess the ability of the sample to donate electrons, with the results shown in Figure 1B. All extracts showed a dose-dependent effect. Again, AE extract was less efficient than AE-D and ME, since only these two extracts showed nearly $100 \%$ activity at a high concentration $(1.0 \mathrm{mg} / \mathrm{mL})$.
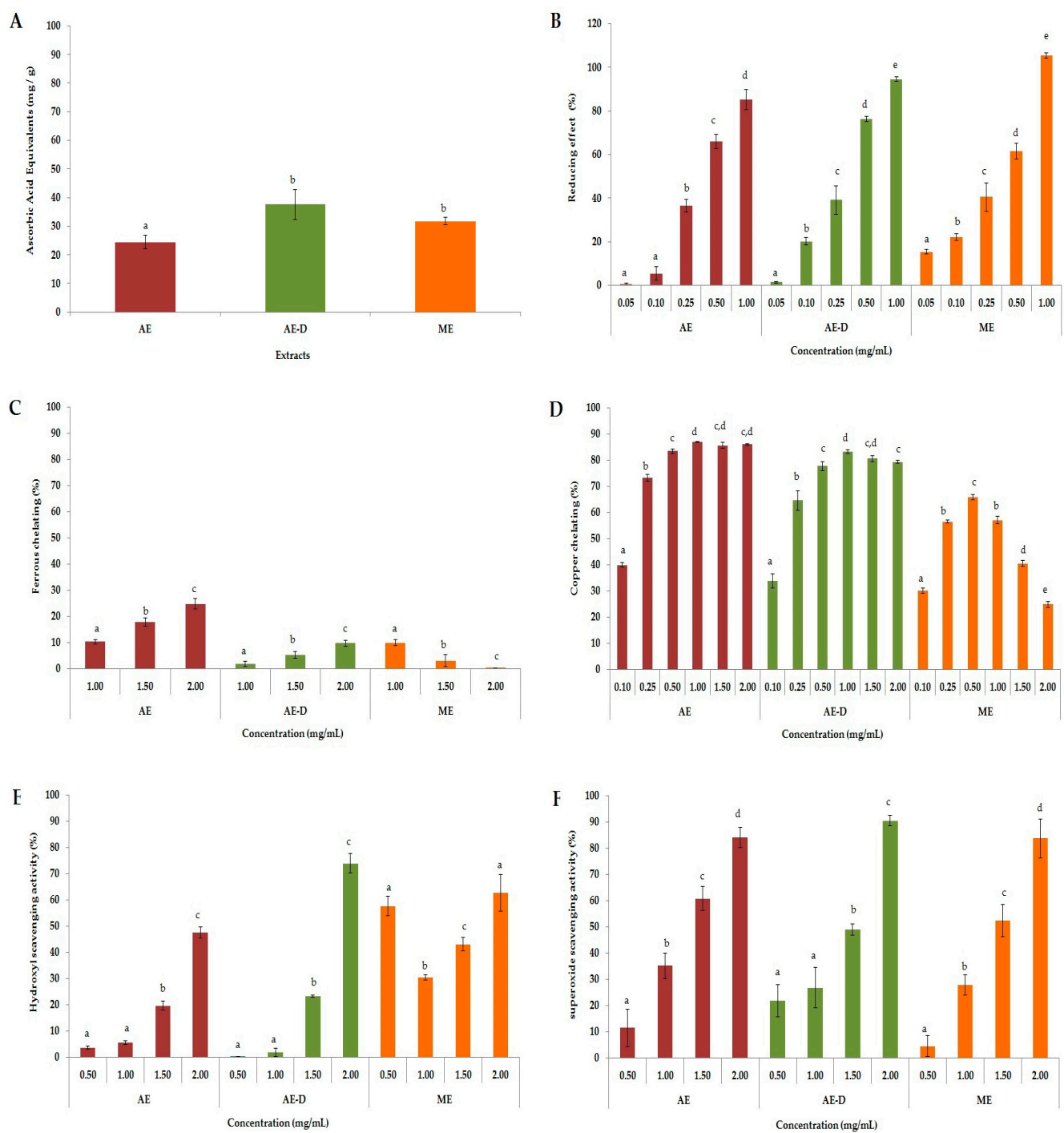

Figure 1. Antioxidant activities of AE (aqueous extract), AE-D (aqueous extract from decoction) and ME (methanol extract): (A) total antioxidant capacity; (B) reducing power; (C) ferrous chelating; (D) copper chelating; (E) hydroxyl radical scavenging; and (F) superoxide radical scavenging. Letters a,b,c,d represent the presence of significant difference between different concentration of the same extract as determined using one-way analyses of variance (ANOVA) followed by the Student's $t$-test $(p<0.05)$.

All three extracts presented ferric chelating activity (Figure 1C), but, in this case, AE was the most potent extract ( $25 \%$ activity), whereas the activity of AE-D and ME did not exceed $15 \%$. Overall, the ferric chelating activity of the three extracts was very low compared to their cupric chelating activity. As shown in Figure 1D, AE and AE-D extracts exhibited a marked and dose-dependent cupric chelating activity, with approximately $86 \%$ and $83 \%$ of chelation, respectively. The maximal chelating activity of ME was $65 \%(0.5 \mathrm{mg} / \mathrm{mL})$, but, with increasing concentration, this value decreased. 
The results of the hydroxyl radical scavenging assay (Figure $1 \mathrm{E}$ ) showed that the $0.5 \mathrm{mg} / \mathrm{mL}$ dose of ME showed an activity of $\sim 60 \%$, but this effect did not increase at higher doses. In contrast, AE and AE-D showed a dose-dependent effect, reaching saturation around $50 \%$ and $70 \%$, respectively. With regard to the superoxide ion scavenging ability of $B$. trimera, we observed that all extracts showed a dose-dependent effect (Figure 1F), reaching saturation at approximately $90 \%$.

\subsection{Determination of the Amount of Protein, Sugar and Phenolic Compounds in the Extracts}

The amount of protein, sugar, and phenolic compounds in the three extracts is shown in Table 1. There were fewer sugar and phenolic compounds in $\mathrm{ME}$ than in $\mathrm{AE}$, although ME possessed the largest amount of proteins. AE and AE-D showed similar results, suggesting that decoction did not change the amount of protein, sugar, or phenolic compounds that are extracted with water.

Table 1. The amount of sugar, protein and phenolic compounds in Baccharis trimera extracts.

\begin{tabular}{cccc}
\hline Compounds & AE & AE-D & ME \\
\hline Sugar (mg) & $18.4 \pm 0.84^{\mathrm{a}}$ & $23.7 \pm 0.23^{\mathrm{a}}$ & $14.1 \pm 0.19^{\mathrm{b}}$ \\
Proteins (mg) & $5.2 \pm 0.15^{\mathrm{a}}$ & $5.8 \pm 1.21^{\mathrm{a}}$ & $8.8 \pm 0.97^{\mathrm{b}}$ \\
Phenolic (mg) & $25.8 \pm 1.28^{\mathrm{a}}$ & $29.4 \pm 0.64^{\mathrm{a}}$ & $20.7 \pm 0.66^{\mathrm{b}}$ \\
\hline
\end{tabular}

$\mathrm{AE}$, aqueous extract; $\mathrm{AE}-\mathrm{D}$, aqueous extract from decoction; $\mathrm{ME}$, methanol extract. Letters a,b represent a significant difference between the samples by the one-way analysis of variance analyses (ANOVA) followed by the Student's $t$-test $(p<0.05)$.

\subsection{Antiproliferative Assay}

In order to investigate the anti-proliferative effect of the B. trimera extracts, 3T3-L1 cells were treated with different concentrations of the three extracts and cellular viability was assessed via BrdU assay. As shown in Figure 2, treatment with AE and AE-D (0.05-1.00 mg/mL) for 24 or $48 \mathrm{~h} \mathrm{did} \mathrm{not}$ affect the proliferation of 3T3-L1. In contrast, treatment with ME did affect 3T3-L1 cell proliferation. After $24 \mathrm{~h}, \mathrm{ME} 0.5 \mathrm{mg} / \mathrm{mL}$ and $1.0 \mathrm{mg} / \mathrm{mL}$ decreased the proliferation of 3T3-L1 by approximately $40 \%$ and $75 \%$, respectively. After $48 \mathrm{~h}$, this inhibition was greater than that previously observed and ME $0.25 \mathrm{mg} / \mathrm{mL}$ also inhibited 3T3-L1 proliferation. Due to this result, ME was not used in the following assays.

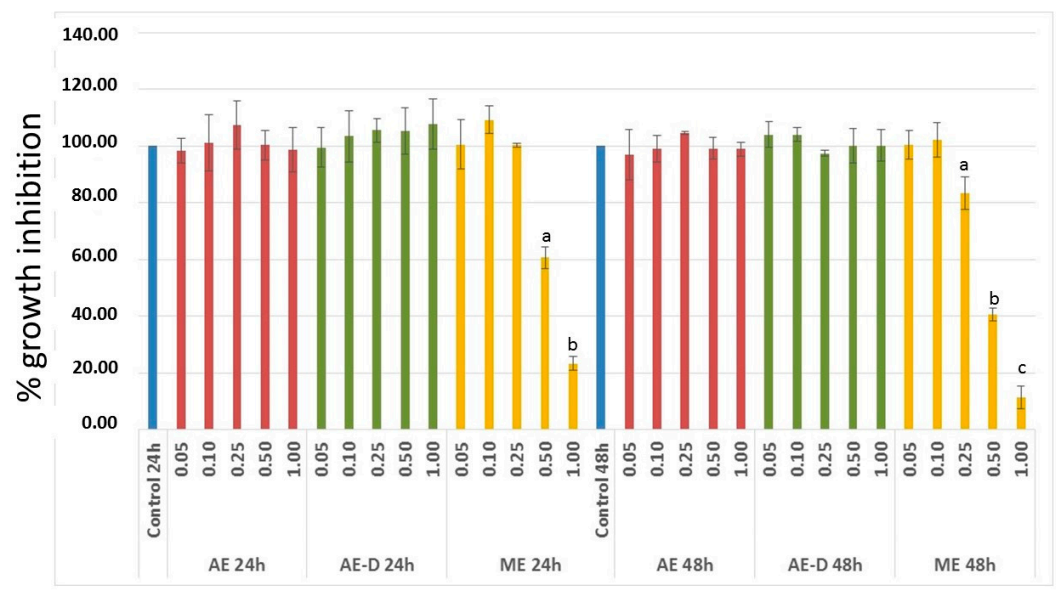

Figure 2. The effect of aqueous extract (AE), decoction extract (AE-D), and methanol extract (ME) on 3T3-L1 cell proliferation. 3T3-L1 cell proliferation was carried out in the presence or absence of extracts $(0,0.05,0.1,0.25,0.5$, and $1 \mathrm{mg} / \mathrm{mL})$. The rate of cell proliferation inhibition was determined using BrdU. The results are expressed as mean \pm SD of four determinations. Letters $a, b, c$, indicate significantly differences between different concentrations and the control according to one way analysis of variance (ANOVA) followed by the Student's $t$-test $(p<0.05)$. 


\subsection{Effect of B. trimera Extracts on Intracellular Lipid Accumulation}

The effect of AE and AE-D on adipogenesis was assessed using 3T3-L1 cells in the presence of adipogenic medium (MDI: dexamethasone, IBMX, insulin, and fetal bovine serum) with the addition of various concentrations of AE or AE-D. The size and number of lipid droplets in 3T3-L1 adipocytes after AE and AE-D treatment were visualized using microscopy. After approximately three days of incubation in the presence of MDI, 3T3-L1 cells started to exhibit the morphology of adipocytes, including intracellular accumulation of fat droplets (Data not shown). After 15 days, the cells were stained with Oil Red O (ORO). Undifferentiated 3T3-L1 (negative control) contained fewer lipid droplets than treated cells (Figure 3A). In contrast, the number of droplets was greater in mature 3T3-L1 adipocytes (positive control). The number and size of lipid droplets decreased in mature 3T3-L1 adipocytes treated with 0.5 and $1.0 \mathrm{mg} / \mathrm{mL} \mathrm{AE}$ or AE-D, whereas the extracts at a concentration of $0.1 \mathrm{mg} / \mathrm{mL}$ did not affect these parameters.

The levels of lipid accumulation into 3T3-L1 cells after AE and AE-D treatment were quantified using ORO staining. As shown in Figure 3B, the amount of intracellular ORO extracted from undifferentiated 3T3-L1 cells corresponded to only 50\% the amount found in mature adipocytes (control, defined as $100 \%$ fat droplet content). Moreover, extracts at a low concentration $(0.1 \mathrm{mg} / \mathrm{mL})$ did not decrease the ORO amount extracted from cells. However, the level of ORO decreased significantly after treatment with 0.5 and $1.0 \mathrm{mg} / \mathrm{mL}$ of either extract (Figure 3B).

A
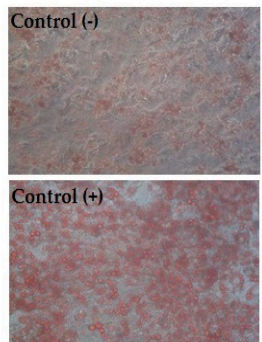

120
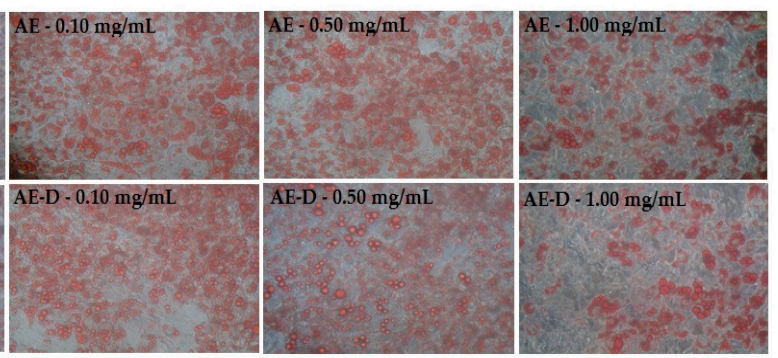

B

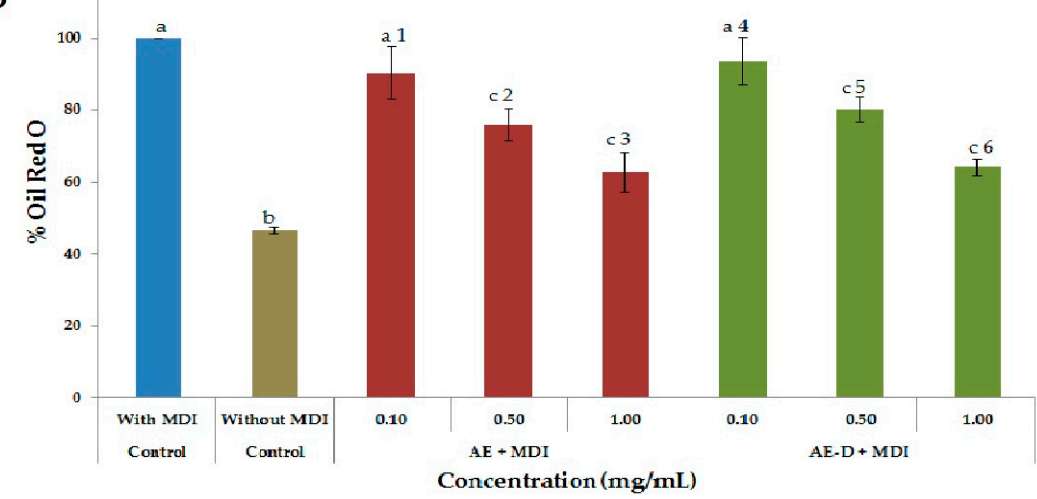

Figure 3. Adipocytes stained with the dye Oil Red O after 15 days after the onset of differentiation. (A) Intracellular lipid accumulation in 3T3-L1 cells treated with adipogenic medium (MDI) and different concentrations of AE or AE-D. After 15 days of treatment the cells were stained with oil Red O, observed with a microscope and photographed (20× magnification). (B) Baccharis trimera extracts inhibited the differentiation of 3T3-L1 preadipocytes into mature adipocytes. Oil Red O dye was used to stain the adipocytes 15 days after treatment with the extracts. Stained oil droplets were dissolved with isopropanol and evaluated by spectrophotometric analysis at $510 \mathrm{~nm}$. The optical density in cells treated only with MDI was taken as $100 \%$ of relative lipid content. Values are expressed as mean \pm standard deviation $(n=3)$. Letters $\mathrm{a}, \mathrm{b}, \mathrm{c}$ indicate significant differences between different concentrations with the control. Numbers 1,2,3,4,5,6 indicate significantly differences between different concentrations of same extract according to one-way analysis of variance (ANOVA) followed by the Student's $t$-test $(p<0.05)$. 


\subsection{Determination of Free Glycerol in 3T3-L1 Cells Medium}

3T3-L1 cells were seeded into plates and induced to differentiate into mature adipocytes in the presence or absence (positive control) of extracts, as described above. After 15 days, the amount of free glycerol in the culture medium was measured. A very low level of glycerol was present in the medium of undifferentiated 3T3-L1 cells, and increased approximately six times in the medium of mature 3T3-L1 adipocytes (Figure 4). In contrast, the effect of glycerol decreased in the presence of extracts in a dose-dependent manner.

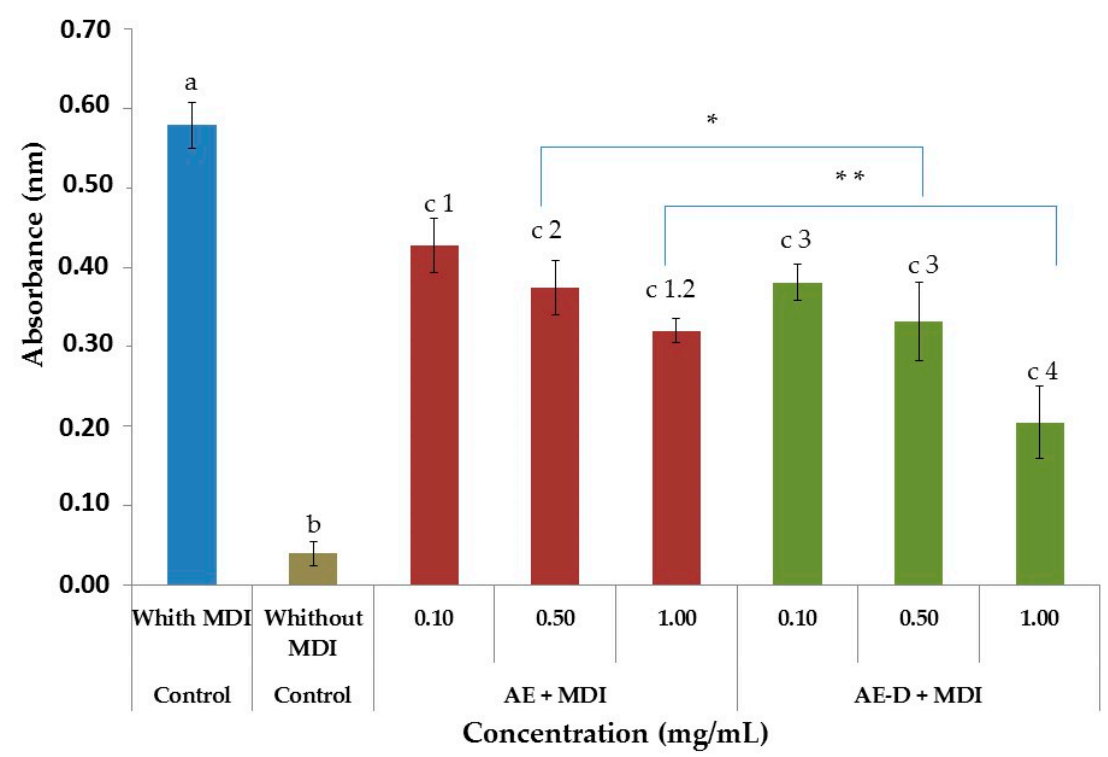

Figure 4. Induction of hydrolysis of intracellular lipids by Baccharis trimera aqueous extract (AE) and aqueous extract with decoction (AE-D). The induction of intracellular lipids hydrolysis was determined by quantification of glycerol released into the culture medium. An aliquot of the culture medium after the last change of medium was used to quantify free glycerol. Values are expressed as mean \pm standard deviation $(n=3)$. Letters $\mathrm{a}, \mathrm{b}, \mathrm{c}$ indicate significant differences between different concentrations with the control. Numbers 1,2,3,4 indicate significant differences between different concentrations of same extract. * and ${ }^{* *}$ indicate significant differences between AE $0.5 \mathrm{mg} / \mathrm{mL}$ and AE-D $0.5 \mathrm{mg} / \mathrm{mL}$ and between AE $1.0 \mathrm{mg} / \mathrm{mL}$ and AE-D $1.0 \mathrm{mg} / \mathrm{mL}$ according to one-way analysis of variance (ANOVA) followed by the Student's $t$-test $(p<0.05)$.

\subsection{B. trimera Extracts Affect the Levels of C/EBP $\alpha, C / E B P \beta$ and $P P A R \gamma$}

After 15 days of differentiation, the 3T3-L1 cells were lysed and the levels of C/EBP $\alpha, C / E B P \beta$, and PPAR $\gamma$ were measured via Western blotting analysis. As shown in Figure 5, expression of C/EBP $\beta$ and PPAR $\gamma$ significantly increased in the presence of $0.1 \mathrm{mg} / \mathrm{mL}$ of both extracts, while the level of $\mathrm{C} / \mathrm{EBP} \alpha$ was not affected.

When the concentration of the samples was increased from 0.1 to $0.5 \mathrm{mg} / \mathrm{mL}$, in the presence of both extracts the levels of all proteins decreased. In addition, this decrease was more pronounced when the cells were treated with AE-D. In case of this extract, the expression of $\mathrm{C} / \mathrm{EBP} \alpha, \mathrm{C} / \mathrm{EBP} \beta$, and PPAR $\gamma$ decreased $75 \%, 78 \%$, and 79\%, respectively, compared to the levels observed when cells were exposed to $0.1 \mathrm{mg} / \mathrm{mL}$ extract.

The best inhibition levels were obtained when the cells were exposed to $1.0 \mathrm{mg} / \mathrm{mL}$ of each extract. In the presence of $\mathrm{AE}$, the level of the three proteins decreased to below $80 \%$. However, the effect of AE-D was more evident since it decreased the level of all three proteins by $90 \%$. 


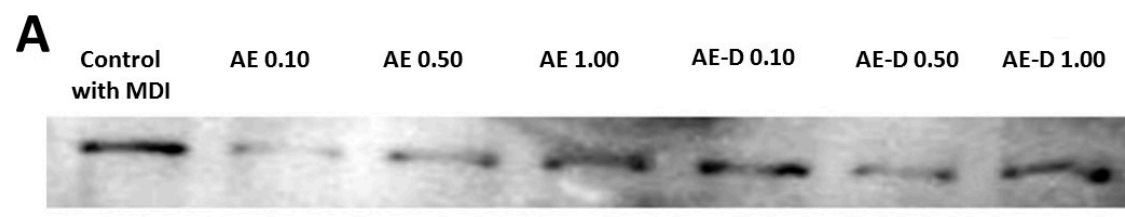

$\beta$-actin

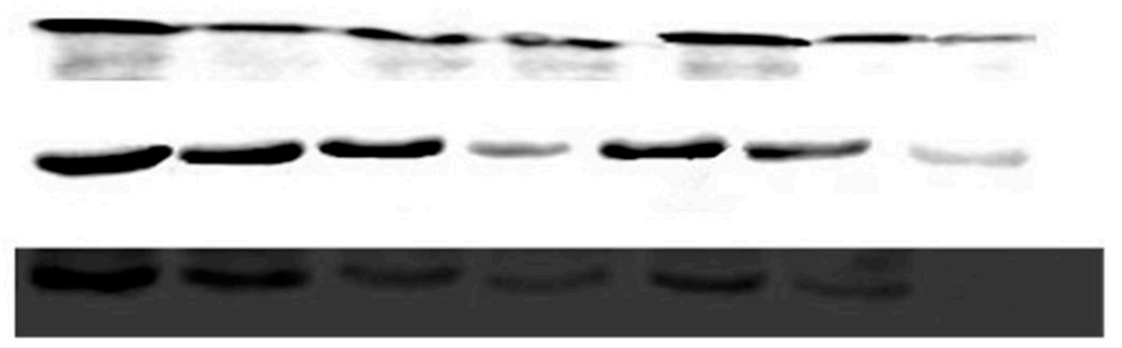

C/EBPa

C/EBP $\beta$

PPARY

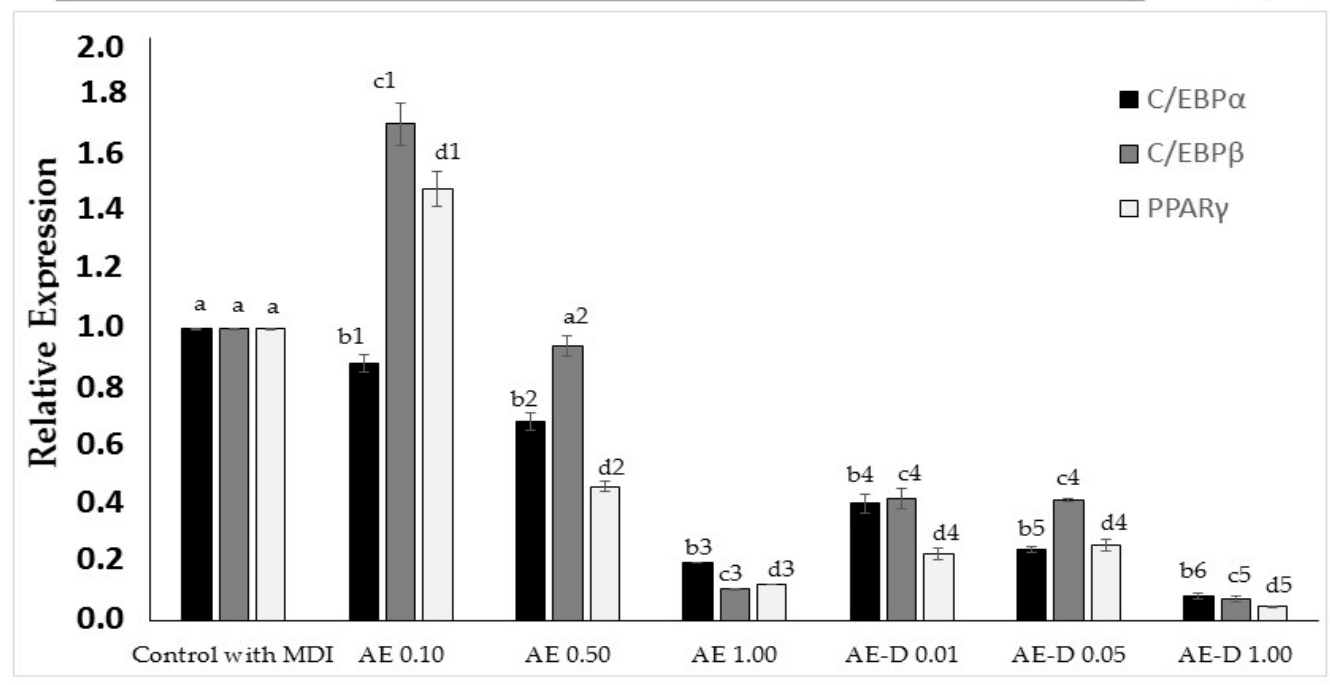

Figure 5. Effects of Baccharis trimera aqueous extract (AE) and AE with decoction (AE-D), both with adipogenic growth medium (MDI), on the expression of adipocyte markers. (A) Equal amounts of protein $(50 \mu \mathrm{g})$ of cell lysate were analyzed by Western blotting to detect $\beta$-actin, CCAAT enhancer-binding protein $\alpha(\mathrm{C} / \mathrm{EBP} \alpha)$, CCAAT enhancer-binding protein $\beta(\mathrm{C} / \mathrm{EBP} \beta)$, and gamma receptors by peroxisome proliferators (PPAR $\gamma$ ) levels; $(B)$ The graph of the protein relative expressions was obtained as described in materials and methods. Control, Control with MDI. Values are expressed as mean \pm standard deviation $(n=3)$. Letters $\mathrm{a}, \mathrm{b}, \mathrm{c}, \mathrm{d}$ indicate significant differences between different concentrations and the control. Numbers 1,2,3,4,5 indicate significant differences between each protein analyzed in the different concentrations between each extract as calculated by one-way analysis of variance (ANOVA) followed by the Student's $t$-test $(p<0.05)$.

2.7. High-Performance Liquid Chromatography with Diode Array Detection (HPLC-DAD) Profile of AE and $A E-D$ Extracts from $B$. trimera

The chromatographic fingerprints of AE and AE-D, obtained using HPLC-DAD, are depicted in Figures 6 and 7, respectively.

The chromatogram of the heated AE-D of B. trimera obtained using Methods 1 and 2 showed absorption characteristics similar to those of flavonoids and phenolic acids at the wavelengths analyzed, with at least 15 peaks in the chromatogram at a wavelength of $340 \mathrm{~nm}$ for Method 1 (see Materials and Methods), and 10 peaks for Method 2 (see Materials and Methods) (Figure 6A,B). Among the flavonoids, most had a UV spectrum similar to glycosylated flavonoids derived from apigenin $(267 \mathrm{~nm}$ II band and $336 \mathrm{~nm}$ I band). 

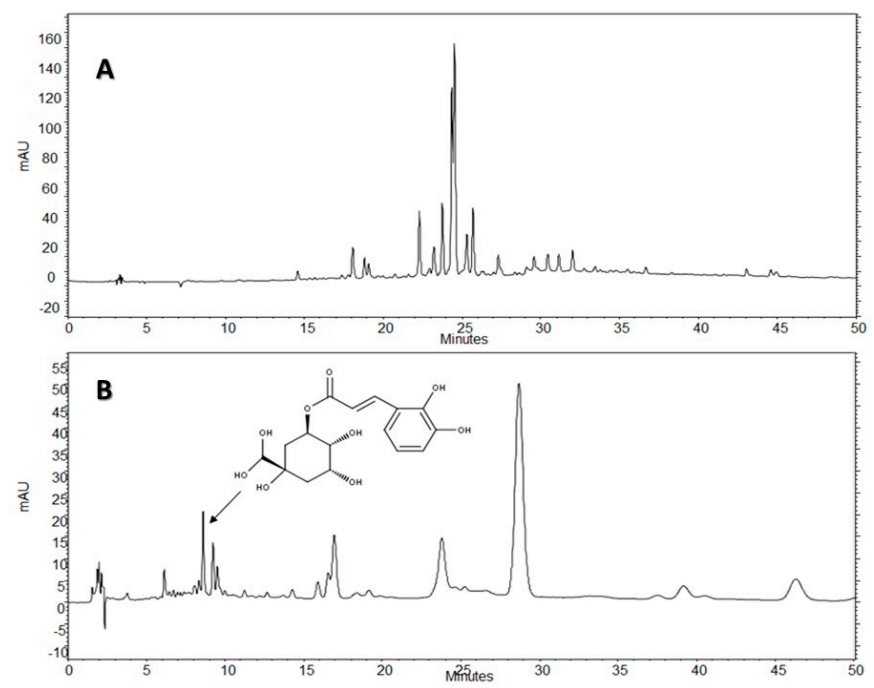

Figure 6. Chromatogram from a high performance liquid chromatography with diode array detector (HPLC-DAD) trial of the aqueous extract with decoction (AE-D) of Baccharis trimera: (A) Method 1; and (B) Method 2. SP: column C18 Phenomenex-Luna ${ }^{\circledR}(250 \times 4.6 \mathrm{~mm}, 5 \mu \mathrm{m})$; Mobile phase: acetonitrile gradient: acetic acid 0.3\%; Detection: $340 \mathrm{~nm}$. Chlorogenic acid was identified (arrow).

The chromatogram of the AE of B. trimera using Methods 1 and 2 showed absorption characteristics similar to those of flavonoids and phenolic acids at the wavelengths tested, with at least 17 peaks in the chromatogram at a wavelength of $340 \mathrm{~nm}$ using Method 1, and 13 peaks using Method 2 (Figure 7A,B). Therefore, in the AE extract, most flavonoids had a UV similar spectrum to glycosylated flavonoids derived from apigenin.
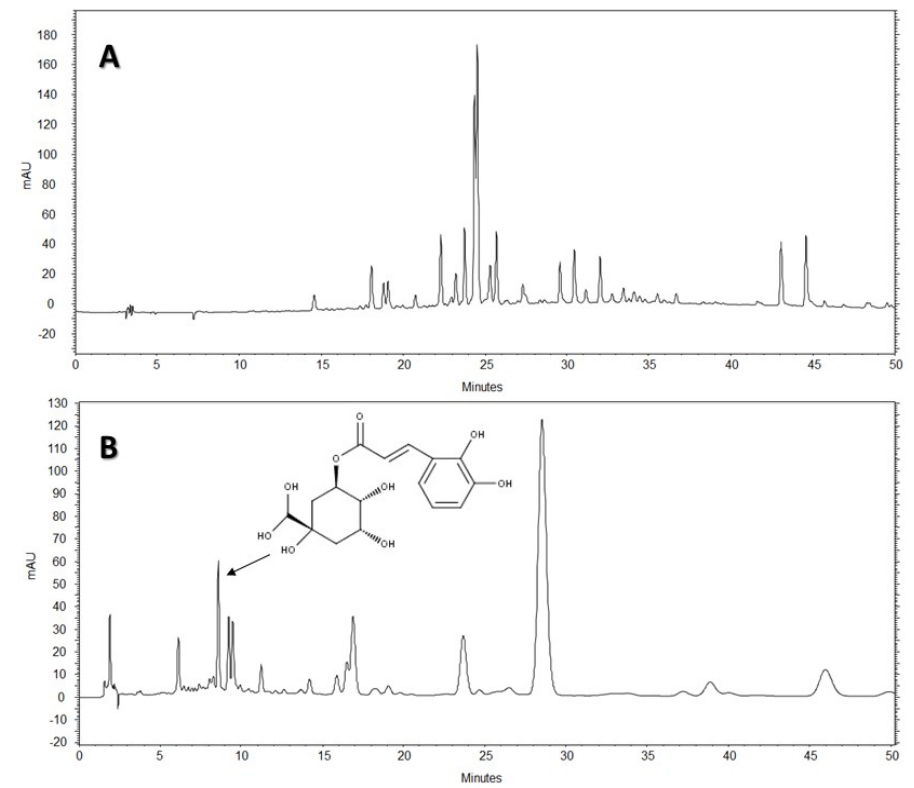

Figure 7. Results from high-performance liquid chromatography with diode array detector (HPLC-DAD) of the aqueous extract (AE) of Baccharis trimera: (A) Method 1; and (B) Method 2. SP: column C18 Phenomenex-Luna ${ }^{\circledR}(250 \times 4.6 \mathrm{~mm}, 5 \mu \mathrm{m})$; Mobile phase: acetonitrile gradient: acetic acid $0.3 \%$; Detection: $340 \mathrm{~nm}$. Chlorogenic acid was identified (arrow).

As shown in Figures 6 and 7, there were significant differences between the chromatographic profiles presented by the $\mathrm{AE}-\mathrm{D}$ and $\mathrm{AE}$ from $B$. trimera, demonstrating that the method used to obtain the 
extract can interfere with its qualitative and quantitative composition. In the chromatogram at $340 \mathrm{~nm}$ for both Methods 1 and 2, the extracts showed similar composition, differing mainly in the amount of the compounds. The AE had the largest compound content, especially in relation to the major peak.

Standards peaks were compared to the corresponding peaks in the extracts according to the $t R$ and UV spectra, suggesting that chlorogenic acid (CGA) was the peak seen at 8.60 min and UV $325 \mathrm{~nm}$ in Method 1. Thereafter, by the analysis of standards and co-injection of extract + standard, it was possible to observe the increase in peak area for this standard analyzed. This suggests, once again, that CGA may be present in extracts.

\section{Discussion}

The presence of a large amount of reactive oxygen species (ROS) in preadipocyte cytoplasm is related to the acceleration of adipocyte differentiation through the expression of adipogenic genes in response to oxidative stress [18]. Furthermore, antioxidant and anti-adipogenic effects of several natural compounds are known to suppress adipogenesis by preventing increased ROS levels [8]. The decrease in excessive ROS levels and the inhibition of adipocyte differentiation are important strategies for preventing various chronic diseases related to oxidative stress and obesity. With this in mind, we first evaluated the antioxidant potential of B. trimera extracts.

ROS are formed through a chain reaction involving three steps (initiation, propagation, and termination). Thus, different methods were used to evaluate the antioxidant properties of $\mathrm{AE}$, AE-D and ME at different stages: initiation (total antioxidant capacity (TAC) and reducing power), propagation (chelation of copper and iron), and termination (scavenging of the hydroxyl superoxide radical and of hydrogen peroxide), as shown in Figure 1.

In the TAC assay, our results were similar to those obtained by Oliveira et al. [19]. However, our work is the first to evaluate $B$. trimera extracts via a reducing power assay. Both of these tests evaluated the capacities of the samples to donate electrons and/or a hydrogen atom and break the free radical chain, however the test conditions are not similar. Therefore, when a compound acts as a donor in these two tests, it is an indication that it can act as an antioxidant in different conditions, such as in different cellular microenvironments.

All $B$. trimera extracts were able to scavenge superoxide radicals in a dose-dependent manner (Figure 1F). The superoxide radical is a highly toxic species produced by innumerable biological and photochemical reactions. This radical is a ROS that can damage various molecules, including proteins, lipids, and cellular DNA, causing cell and tissue damage as well as a number of diseases [20]. It is produced in vivo and leads to the formation of hydrogen peroxide $\left(\mathrm{H}_{2} \mathrm{O}_{2}\right)$, another oxidant agent very harmful to cells, via a dismutation reaction. Thus, by scavenging superoxide radicals, the extracts also inhibit the formation of $\mathrm{H}_{2} \mathrm{O}_{2}$.

In cells, $\mathrm{H}_{2} \mathrm{O}_{2}$ reacts with transition metal ions such as $\mathrm{Cu}^{2+}$ and $\mathrm{Fe}^{2+}$ to generate hydroxyl radicals via Fenton or Haber-Weiss reactions. The hydroxyl radical is the most reactive of ROS, causing serious damage to biomolecules. Its elimination is highly desirable since the elevated reactivity of this radical is associated with cellular damage, leading to several diseases [21]. In our study, all three extracts, particularly AE-D and ME, showed hydroxyl radical scavenging activity. Vieira and Co-workers [22] have also shown that aqueous and ethanol $B$. trimera extracts were able to scavenge hydroxyl radicals. They demonstrated that the aqueous extract was a stronger scavenger than the ethanol extract, which agrees with our data. However, these authors did not address whether the plant extracts only scavenge hydroxyl radicals or if they also act as a metal chelator. Our results show that the extracts have also metal chelating activity, especially copper chelating action, which also leads to a reduction in hydroxyl radical generation.

Still with respect to the chelating activity of the extracts. We can see in Figure 1, that all the extracts showed a much higher chelating activity of copper than the chelating activity of copper. Aqueous extracts of B. trimera have in their composition ruthin [11], apigenin, quercetin, and luteolin [23]. These phenolic compounds are agents with high copper chelating capacity and low iron chelating capacity $[24,25]$. What justifies the high copper chelating activity of aqueous extracts of $B$. trimera. 
Overall, our data showed the great potential of the B. trimera extracts as antioxidant agents. The scavenging action of plant extracts has been correlated to the presence of phenolic compounds [26]. Indeed, we found large amount of these compounds in the extracts (Table 1). However, ME showed similar antioxidant activity to other extracts, although it contains fewer phenolic compounds. One possible explanation is that the different conditions of extraction allowed ME to contain large amounts of phenolic compounds that act as antioxidants. Another possibility is that the methanol extracted some compounds that were not extracted by water, and that these compounds are more powerful than those found in AE and AE-D. However, the confirmation of these hypotheses requires further investigations.

Transition metal ions including $\mathrm{Cu}^{2+}$ and $\mathrm{Fe}^{2+}$ can increase adipose tissue mass in rats [27]. Furthermore, since these metals increase the expression of adipogenic transcriptional factors, they contribute to 3T3-L1 cell differentiation. Excessive ROS generation is associated with increased lipid accumulation during adipocyte differentiation [28]. With this in mind, and after we identified the potent antioxidant activity of the extracts as both copper chelators and ROS scavengers, we decided to evaluate the anti-adipogenic activity of these extracts.

3T3-L1 cells have served as a well-documented model system used to develop anti-adipogenic agents. Therefore, it was first necessary to assess the effect of the extracts on the viability of these cells. Since ME showed anti-proliferative activity against 3T3-L1 cells (Figure 2), it was not used in next steps of this study.

As shown in Figure 3A,B and Figure 4, the AE and AE-D were able to reduce the amount of neutral lipids within the cell, a fact evidenced by the reduced staining in the cells. In order to understand their effect, we also determined the level of the transcription factors $C / E B P \beta, \operatorname{PPAR} \gamma$, and $C / E B P \alpha$ that play key roles in the complex transcriptional cascade of adipocyte differentiation. An increase in these factors in turn leads to increased levels of molecules involved in lipid synthesis such as fatty acid synthase, fatty acid binding protein, leptin, and adiponectin [29]. The results of the trial showed that C/EBP $\beta, P P A R \gamma$, and C/EBP $\alpha$ levels in the 3T3-L1 cells were reduced after treatment with AE and AE-D (Figure 5).

However, these data still need to be understood. The blotting analysis showed AE and AE-D $(0.10 \mathrm{mg} / \mathrm{mL})$ at low concentration stimulates the expression of PPAR $\gamma$ and C/EBP $\beta$. However, an adipogenic effect was not observed (Figures 3 and 4), probably because the level of C/EBP $\alpha$ are not high. $\mathrm{C} / \mathrm{EBP} \beta$ is known to be a central factor in adipocyte diffusion and regulates $\mathrm{C} / \mathrm{EBP} \alpha$ levels $[4,5]$. Thus, the data obtained here lead us to propose that there are one or more compounds in the extracts that prevent the action of $\mathrm{C} / \mathrm{EBP} \beta$ on $\mathrm{C} / \mathrm{EBP} \alpha$. However, the confirmation of these hypotheses requires further investigations.

B. trimera extracts have been identified as anti-obesity agents [13-15]. However, to our knowledge, there are no other groups that have evaluated the effect of B. trimera extracts as anti-adipogenic agents, which made a comparison of our results with those from other research groups impossible. Nevertheless, based on our data, we can say that the extracts are anti-adipogenic agents.

The HPLC-DAD analysis showed that AE-D and AE extracts contain several different types of phenolic compounds (Figures 6 and 7). This result is consistent with those of previous reports. In fact, phytochemical analyses of $B$. trimera extracts showed the presence of several phenolic compounds such as rutin [11], eupafolin, hispidulin, apigenin, quercetin, and luteolin, [23], of which these last three and rutin are possible anti-obesity agents [9]. In our study, the data suggest the presence of CGA in B. trimera extract composition. CGA acts as donor of hydrogen atoms to reduce free radicals and to inhibit oxidation reactions, becoming oxidized to its phenoxyl radical that is quickly stabilized by resonance stabilization as a result [30]. Arçari and co-workers [31] showed that CGA is a more potent anti-adipogenic compound than rutin and quercetin, since even after using a tenfold amount of these molecules, they failed to achieve the same degree of adipogenesis inhibition that they obtained using CGA. Thus, we suggested that CGA is another molecule responsible for the anti-adipogenic activity of $B$. trimera extracts.

Before the all data, a question arose. Why was EA-D a more potent anti-adipogenic agent than AE? The HPLC-DAD analysis showed similar composition of these extracts, differing mainly in the concentration of the compounds. In fact, the $\mathrm{AE}$ extract showed the highest content of active compounds. However, AE-D was more powerful than AE in three different antioxidant tests 
(TAC, reducing power, and hydroxyl radical scavenging). Thus, we do not rule out the possibility that additional compound(s) present in the AE-D that are not found in the AE might also show anti-adipogenic activity. The confirmation of this hypothesis requires further investigations.

\section{Materials and Methods}

\subsection{Materials}

Potassium ferricyanide, ferrous sulfate (II), ethylenediaminetetraacetic acid (EDTA), gallic acid, ammonium molybdate, hydrogen peroxide $30 \%$, acetic acid, Folin-Ciocalteu phenol reagent, ethanol, and sulfuric acid were obtained from Merck (Darmstadt, Germany). Nitro blue tetrazolium (NBT), monosaccharides, EDTA, ascorbic acid, methionine, bovine serum albumin (BSA), pyrocatechol violet, ascorbic acid, and ammonium molybdate were purchased from Sigma-Aldrich Co. (St. Louis, MO, USA). Sodium bicarbonate, culture media components (Minimum essential Dulbecco's modified Eagle medium (DMEM)), non-essential amino acids, fetal bovine serum, sodium pyruvate, and phosphate buffered saline (PBS) were purchased from Invitrogen Canada Inc. (Burlington, ON, Canada). Acetonitrile (HPLC grade) purchased from Panreac ${ }^{\circledR}$ (São Paulo, Brazil). Acetic acid was provided by Vetec $^{\circledR}$ (São Paulo, Brazil). Water was purified with a Milli-Q system (Millipore ${ }^{\circledR}$, Bedford, MA, USA). All other solvents and chemicals were of analytical grade.

\subsection{Acquisition of B. trimera Extracts}

B. trimera plants were collected in May and June 2012 in Brasilia, DF, Brazil. A specimen (No. 15694) of the plant was deposited in the Herbarium at the Department of Botany, "Universidade Federal do Rio Grande do Norte" (UFRN), Natal, RN, Brazil. The selected shoots were dehydrated in an aerated oven at $45^{\circ} \mathrm{C}$ for three days and then crushed. From the ground material three different extracts were prepared according as described above.

Approximately $100 \mathrm{~g}$ of crushed material was boiled in $250 \mathrm{~mL}$ of water for $10 \mathrm{~min}$ and filtered, concentrated under reduced pressure at $-80{ }^{\circ} \mathrm{C}$, and lyophilized. The sample obtained was named AE-D.

ME was obtained after ground material ( 100 g) was macerated into methanol $(250 \mathrm{~mL})$ for $24 \mathrm{~h}$, at room temperature $\left(\sim 22^{\circ} \mathrm{C}\right)$, under stirring for $24 \mathrm{~h}$ (three replicates). The mixture was then filtered, concentrated under reduced pressure at $-80^{\circ} \mathrm{C}$, and lyophilized.

In order to obtain the aqueous extract $(\mathrm{AE})$, the ground material ( 100 g) was macerated into $250 \mathrm{~mL}$ of distillated water at room temperature under stirring for $24 \mathrm{~h}$. The mixture was then filtered, concentrated under reduced pressure at $-80^{\circ} \mathrm{C}$, and lyophilized.

\subsection{Chemical Analysis}

Total sugar, protein, and phenolic compound contents were determined as described previously [32]. Phenolic compounds were determinate via the Folin-Ciocalteu phenol reagent method using gallic acid as a standard. The amounts of protein were measured using the Coomassie Brilliant Blue reagent, with BSA as a standard. Total amounts of carbohydrates were determined using the phenol- $\mathrm{H}_{2} \mathrm{SO}_{4}$ method with D-glucose as a standard.

\subsection{HPLC-DAD Profile of $A E$ and $A E-D$ Extracts from the Leaves of $B$. trimera}

HPLC-DAD analyses were performed using an HPLC Merck-Hitach ${ }^{\circledR}$ (Hichrom model) instrument equipped with a diode array detector, quaternary pump, oven column, and autoinjector. For the analysis of the compounds, two methods were performed using a Phenomenex ${ }^{\circledR}$ Luna RP-18 column $(250 \times 4.6 \mathrm{~mm}$, $5 \mu \mathrm{m}$ particle size) and the eluents were: (A) acetic acid $0.3 \%$ and (B) acetonitrile. The following gradient $(v / v)$ was applied: 0-50\% B, 0-50 min for Method 1, and 5-10\% B, 0-5 min; 10\% B, 5-50 min for Method 2. Both methods had a total analysis time of $50 \mathrm{~min}$. Flow elution was $1.0 \mathrm{~mL} / \mathrm{min}$ for Method 1 and $1.5 \mathrm{~mL} / \mathrm{min}$ for Method 2, and the injection volume was $20 \mu \mathrm{L}$ for both methods. Detection was performed at 254,280 , and $340 \mathrm{~nm}$, with the acquisition of UV spectra in the range of 200 to $400 \mathrm{~nm}$. 
The AE of $B$. trimera (heated and unheated) was compared against standards of CGA ( $\geq 95 \%)$, ellagic acid $(\geq 95 \%)$, gallic acid $(\geq 95 \%)$, vitexin $(\geq 95 \%)$, all isovitexin $(\geq 98 \%)$, all acquired from Sigma-Aldrich ${ }^{\circledR}$. The AE of B. trimera and standards were mixed in methanol:water, 1:1 (v/v). The final concentration of the extract was $3.0 \mathrm{mg} / \mathrm{mL}$. For standards, the final concentration was $100 \mu \mathrm{g} / \mathrm{mL}$. In this technique, the identification of compounds was based on a comparison of retention times, UV spectra of the major peaks, and the increase in peak area after co-injection of standards and extracts. Each trial was performed in triplicate. After total dissolution and prior to analysis, the samples and solvents were filtered through a $0.45 \mu \mathrm{m}$ membrane (MillexTM, Merck ${ }^{\circledR}$ ).

\subsection{Antioxidant Activity}

The antioxidant activities of $B$. trimera extracts were measured using the methods described by Melo et al. (2014) [33], and/or Melo-Silveira et al. (2014) [34].

\subsubsection{Determination of Total Antioxidant Capacity}

The assay used was based on the reduction of $\mathrm{Mo}^{6+}$ to $\mathrm{Mo}^{5+}$ by the samples and the subsequent formation of a green phosphate-molybdate complex at an acidic $\mathrm{pH}$. Tubes containing extracts and reagent solution $(0.6 \mathrm{M}$ sulfuric acid, $28 \mathrm{mM}$ sodium phosphate, and $4 \mathrm{mM}$ ammonium molybdate) were incubated at $95^{\circ} \mathrm{C}$ for $90 \mathrm{~min}$. After the mixture had cooled to room temperature, the absorbance of each solution was measured at $695 \mathrm{~nm}$ against a blank. The TAC was measured in ascorbic acid $\mathrm{mg} /$ extract $\mathrm{g}$, termed equivalent of ascorbic acid.

\subsubsection{Reducing Power}

The reducing power assay depends on the reduction of the potassium ferricyanide by the samples. Briefly, the $B$. trimera extracts were mixed with a phosphate buffer $0.2 \mathrm{M}(\mathrm{pH}$ 6.6), potassium ferricyanide $(1 \% \mathrm{~m} / \mathrm{v})$ and incubated at $50{ }^{\circ} \mathrm{C}$ for $20 \mathrm{~min}$. One addition of trichloroacetic acid $(10 \% \mathrm{~m} / \mathrm{v})$ was used to in order to stop the reaction. Distilled water and ferrous chloride $(0.1 \% \mathrm{~m} / \mathrm{v})$ were added to the solution and the absorbing capacities were measured at $700 \mathrm{~nm}$. Results were calculated as an activity percentage, considering the largest concentration of ascorbic acid (the standard) as $100 \%$ activity.

\subsubsection{Ferric Chelating}

The chelating ability of samples was evaluated as described below: Each extract at different concentrations was added to the reaction mixture containing $\mathrm{FeCl}_{2}(0.05 \mathrm{~mL}, 2 \mathrm{mM})$ and ferrozine $(0.2 \mathrm{~mL}, 5 \mathrm{mM})$. The mixture was shaken and incubated for $10 \mathrm{~min}$ at room temperature and absorbance of the mixture was measured (562 nm) against a blank. EDTA was used as positive control.

The chelating effect was calculated using the corresponding absorbance (A) in the formula given below, where control is the absorbance in the absence of chelating agents:

$$
\text { Chelating Effect }(\%)=\left(\frac{\mathrm{A}_{\text {control }}-\mathrm{A}_{\text {sample }}}{\mathrm{A}_{\text {control }}}\right) \times 100
$$

\subsubsection{Copper Chelation}

The test was carried out in 96-well microplates with $0.2 \mathrm{~mL}$ of reaction mixture containing varying amount of $B$. trimera extracts, pyrocatechol violet $(4 \mathrm{mM})$, and copper II sulfate pentahydrate (50 mg/mL). All wells were stirred and the solution absorbance was measured at $632 \mathrm{~nm}$. The control group was obtained using the same reagents in the absence of chelating agents. The ability of the $B$. trimera extracts to chelate the copper ion was determinate using the following formula:

$$
\text { Copper chelation }(\%)=\left(\frac{\mathrm{A}_{\text {control }}-\mathrm{A}_{\text {sample }}}{\mathrm{A}_{\text {control }}}\right) \times 100
$$




\subsubsection{Hydroxyl Radical Scavenging Activity Assay}

The Fenton's reaction $\left(\mathrm{Fe}^{2+}+\mathrm{H}_{2} \mathrm{O}_{2} \rightarrow \mathrm{Fe}^{3+}+\mathrm{OH}^{-}+\mathrm{OH}\right)$ was used in order to determinate the scavenging activity of $B$. trimera extracts against the hydroxyl radical. These data were expressed as inhibition rates. Hydroxyl radicals were generated mixing $3 \mathrm{~mL}$ sodium phosphate buffer $(150 \mathrm{mM}$, pH 7.4), $10 \mathrm{mM} \mathrm{FeSO} \cdot 7 \mathrm{H}_{2} \mathrm{O}, 10 \mathrm{mM}$ EDTA, $2 \mathrm{mM}$ sodium salicylate, and $30 \% \mathrm{H}_{2} \mathrm{O}_{2}(200 \mathrm{~mL})$ and varying extract concentrations. In the control, sodium phosphate buffer was replaced by $\mathrm{H}_{2} \mathrm{O}_{2}$. The solutions were incubated at $37^{\circ} \mathrm{C}$ for $1 \mathrm{~h}$, and the presence of $\mathrm{OH}^{-}$was detected by monitoring absorbance at $510 \mathrm{~nm}$. Gallic acid was used as the positive control.

\subsubsection{Superoxide Radical Scavenging Activity Assay}

This test depends on the ability of samples to inhibit the photochemical reduction of nitroblue tetrazolium (NBT) in the riboflavin-light-NBT system. Each $3 \mathrm{~mL}$ of reaction mixture contained $75 \mathrm{mM}$ NBT, $50 \mathrm{mM}$ phosphate buffer (pH 7.8), $2 \mathrm{mM}$ riboflavin, $13 \mathrm{mM}$ methionine, $100 \mathrm{mM}$ EDTA, and $1 \mathrm{~mL}$ sample solution. After the production of blue formazan the increase in absorbance at $560 \mathrm{~nm}$ after 10-min illumination from a fluorescent lamp was determined. The entire reaction assembly was enclosed in a box lined with aluminum foil. An identical reaction was maintained in the dark and used as a blank. The positive control was the Gallic acid. Results were accounted in scavenging percentage.

\subsection{Cell Culture, Differentiation and BrdU Assay}

3T3-L1 preadipocyte cells were purchased from a cell bank in Rio de Janeiro, RJ, Brazil (CR089-BCRJ/UFRJ) and maintained with 10\% FBS/DMEM containing $4.5 \mathrm{~g} / \mathrm{L}$ glucose, $100 \mathrm{U} / \mathrm{mL}$ penicillin, $0.1 \mathrm{mg} / \mathrm{mL}$ streptomycin, and $0.25 \mathrm{mg} / \mathrm{mL}$ amphotericin $\mathrm{B}$ at $37^{\circ} \mathrm{C}$ in $5 \% \mathrm{CO}_{2}$ incubator. Confluent cells were differentiated by incubation with the hormone mixture MDI containing $10 \mu \mathrm{g} / \mathrm{mL}$ insulin, $1 \mu \mathrm{M}$ dexamethasone, and $0.5 \mathrm{mM}$ IBMX, in 10\% FBS/DMEM for $72 \mathrm{~h}$. Thereafter, the cells were maintained in post-differentiation medium containing $10 \mathrm{~g} / \mathrm{mL}$ insulin in $10 \%$ FBS/DMEM in the presence of various concentrations $(0.05 ; 0.10 ; 0.25 ; 0.50$ and $1.00 \mathrm{mg} / \mathrm{mL})$ of $B$. trimera extracts and the medium was replaced every 3 days. The same concentration of $B$. trimera extract was supplemented at 3-day intervals when culture medium was replaced. Differentiation, as measured by the expression of adipogenic markers and appearance of lipid droplets, was completed at Day 15 as measured with the use of the dye Oil Red O.

Anti-proliferative testing was conducted using 5-Bromo-2-Deoxyuridine (BrdU) assay, as described by Nobre et al. 2014 [35]. 3T3-L1 cells were seeded into 96-well plates at a density of $5 \times 10^{3}$ cells / well and allowed to attach overnight in $250 \mu \mathrm{L}$ of fresh medium at culture conditions ( $24 \mathrm{~h}$, at $37^{\circ} \mathrm{C}$ and $2.5 \% \mathrm{CO}_{2}$ ). After $12 \mathrm{~h}$, the medium was removed and the extracts $\mathrm{B}$ in medium was added to a final concentration of $0.05-1.0 \mathrm{mg} / \mathrm{mL}$ and incubated for 24 or $48 \mathrm{~h}$. After incubation, traces of extracts were removed by washing the cells twice with $200 \mu \mathrm{L}$ PBS and the BrdU incorporation was determined according to the manufacturer's instruction (BrdU cell proliferation assay kit-Cell Signaling, Danvers, MA, USA).

\subsection{Oil Red O Staining and Free Glycerol}

At day 15 after the induction of differentiation, cells were stained with Oil Red O. Cells were washed twice with PBS and fixed with 3.7\% formaldehyde for $10 \mathrm{~min}$. Fixed cells were stained with $0.2 \%$ Oil Red O-isopropanol for $1 \mathrm{~h}$ and the excess of stain was washed by $70 \%$ ethanol and water. Cells were then photographed using microscope (Nikon EclypseTi-E). Stained oil droplets was dissolved with isopropanol and quantified by spectrophotometric analysis at $510 \mathrm{~nm}$. The optical density in only-MDI-treated cells was taken as 100\% of relative lipid content. Results were represented as relative lipid contents of each experimental group.

To determine free glycerol, we used a Sigma kit (Sigma-Aldrich Co., St. Louis, MO, USA). The free glycerol reagent was made up according to the manufacturer's instructions at room temperature. 
For the test were prepared solution without samples $(10 \mu \mathrm{L}$ water $+400 \mu \mathrm{L}$ reagent), the standard ( $5 \mu \mathrm{L}$ glycerol $+400 \mu \mathrm{L}$ reagent) and samples (10 $\mu \mathrm{L}$ sample $+400 \mu \mathrm{L}$ reagent). To complete mixing of the components, shaken by inversion and led to heating in a water bath at $37^{\circ} \mathrm{C}$ for $5 \mathrm{~min}$. The absorbance of the mixture was measured at $540 \mathrm{~nm}$ for the quantitative enzymatic determination of glycerol. The blank was used as negative control and the standard as positive. The procedure involves enzymatic hydrolysis by lipase of the triglycerides to glycerol and free fatty acids. The increase in absorbance at $540 \mathrm{~nm}$ is directly proportional to the free glycerol concentration of the sample.

\subsection{Western Blotting Analysis}

3T3-L1 cells were plated in $100 \mathrm{~mm}$ plates and stimulated to differentiate into adipocytes (as described above) in the presence or absence of the sample. After 15 days of differentiation, cells were removed from the plates (two plates per treatment) and subjected to washing in ice cold PBS and centrifugation. To obtain the total cellular protein extract, the cells were re-suspended in lysis buffer (50 mM Tris-HCl (pH 7.4); $1 \%$ Tween 20; $0.25 \%$ sodium deoxycholate; $150 \mathrm{mM} \mathrm{NaCl} ; 1 \mathrm{mM}$ EGTA; $1 \mathrm{mM} \mathrm{Na} \mathrm{VO}_{4} ; 1 \mathrm{mM} \mathrm{NaF}$; and protease inhibitors) for $2 \mathrm{~h}$ on ice.

After removal of cellular debris by centrifugation, the protein concentration of the extracts was determined using Bradford reagent (Bio-Rad, Hercules, CA, USA). The extracts were re-suspended in sample buffer (100 mM Tris- $\mathrm{HCl}$ (pH 6.8), $200 \mathrm{mM}$ dithiothreitol, $4 \%$ sodium dodecyl sulfate (SDS), $0.1 \%$ bromophenol blue and $20 \%$ glycerol), and these solutions were boiled for $5 \mathrm{~min}$. For each sample, approximately $30 \mu \mathrm{g}$ of protein was subjected to SDS-polyacrylamide gel electrophoresis (PAGE) with subsequent transfer to polyvinylidene fluoride (PVDF) membranes (Millipore, Bedford, MA, USA). The membranes were blocked by a solution containing nonfat milk $(1 \%)$ or albumin $(1 \%)$ in tris-buffered saline $\left(0.05 \%\right.$ ) and Tween 20 (TBST buffer) and incubated $12 \mathrm{~h}$ at $4{ }^{\circ} \mathrm{C}$ with appropriate primary antibody at a dilution of 1:1000. After further washing in TBST buffer, the membranes were incubated with appropriate secondary antibody (anti-mouse or anti-rabbit) conjugate with peroxidase (dilution 1: 1000) in blocking buffer for $1 \mathrm{~h}$. Detection was performed using chemiluminescence.

The bands in the gel were quantified by densitometry and a ratio between the values obtained for the $\mathrm{C} / \mathrm{EBP} \alpha, \mathrm{C} / \mathrm{EBP} \beta$, and PPAR $\gamma$ proteins and the value obtained for actin was used to construct Figure 5.

The primary antibodies used specific for $\beta$-actin (sc-130656) were purchased from Santa Cruz Biotechnology, Inc. (Santa Cruz, CA, USA); C/EBP $\alpha$ (8178), C/EBP $\beta$ (3087), and PPAR $\gamma$ (2443) were obtained from Cell Signaling Technology (Beverly, MA, USA). The horseradish peroxidase (HRP) Secondary antibodies were also obtained from Cell Signaling Technology (Beverly, MA, USA).

\subsection{Statistical Analysis}

All experiments were repeated at least three times, and all values are given as mean \pm standard deviation (S.D.) of triplicates. One-way analysis of variance (ANOVA) followed by a Student's $t$-test was used to analyze statistical significance. Results with $p<0.05$ were considered as statistically significant.

\section{Conclusions}

This report suggests that $B$. trimera extracts have antioxidant activity, prevent many diseases caused by oxidative stress, and can attenuate adipogenesis during the adipogenic differentiation process, since they were anti-adipogenic and antioxidant agents. The beneficial role of $B$. trimera on obesity is connected to its antioxidant actions. $B$. trimera extracts, especially AE-D, regulate adipogenesis by decreasing the levels of the adipogenic transcription factors $C / E B P \alpha, C / E B P \beta$, and PPAR $\gamma$. In addition, we suggested the presence of CGA in B. trimera, and it may be another molecule responsible for in the B. trimera anti-adipogenic effect. This is the first study to demonstrate the potential effect of B. trimera in the differentiation of preadipocyte 3T3-L1 into adipocytes. Thus, we suggest that $B$. trimera shows promise as an alternative to available therapeutic strategies for obesity. However, more studies are needed to understand and clarify the mechanisms of action of B. trimera in weight loss. 
Acknowledgments: We thank the Conselho Nacional de Desenvolvimento Científico e Tecnológico (CNPq), the Coordenação de Aperfeiçoamento de Pessoal de Nível Superior (CAPES), and the Ministério de Ciência, Tecnologia, Inovações e Comunicações (MCTIC — the Science and Technology Ministry in Brazil) for their financial support in the form of grants and scholarships. Rafael Camara and Ruth Oliveira and Dayanne Gomes thank the PhD scholarship from CAPES. Hugo A. O. Rocha is a CNPq fellowship honored researcher. This research was presented at Programa de Pós-Graduação em Ciências da Saúde at Universidade Federal do Rio Grande do Norte, as part of the M.Sc dissertation of Daniele Nascimento.

Author Contributions: Daniele de Souza Marinho do Nascimento prepared the samples. Daniele de Souza Marinho do Nascimento and Mariana Santana Santos Pereira Costa performed the chemical analysis. Daniele de Souza Marinho do Nascimento, Ruth Medeiros Oliveira and Rafael Barros Gomes Camara performed anti-adipogenic and cytotoxic tests. Daniele de Souza Marinho do Nascimento and Dayanne Lopes Gomes performed the antioxidant tests. Júlia Moraes Fernandes and Silvana Maria Zucolotto Langassner performed the HPLC analysis. Jessika Fernanda Santiago Monte and Ruth Medeiros Oliveira performed Western blotting. Daniele de Souza Marinho do Nascimento analyzed the data. Daniele de Souza Marinho do Nascimento, Júlia Moraes Fernandes and Hugo Alexandre Oliveira Rocha wrote the paper. Hugo Alexandre Oliveira Rocha funds and revised the paper.

Conflicts of Interest: The authors declare no conflict of interest.

\section{References}

1. WHO Obesity and Overweight. Available online: http://www.who.int/mediacentre/factsheets/fs311/en/ (accessed on 1 August 2016).

2. Ross, M.G.; Desai, M. Developmental programming of offspring obesity, adipogenesis, and appetite. Clin. Obstet. Gynecol. 2013, 53, 529-536. [CrossRef] [PubMed]

3. Fève, B. Adipogenesis: Cellular and molecular aspects. Best Pract. Res. Clin. Endocrinol. Metab. 2005, 19, 483-499. [CrossRef] [PubMed]

4. Siersbaek, R.; Nielsen, R.; Mandrup, S. Transcriptional networks and chromatin remodeling controlling adipogenesis. Trends Endocrinol. Metab. 2012, 23, 56-64. [CrossRef] [PubMed]

5. Siersbaek, R.; Mandrup, S. Transcriptional networks controlling adipocyte differentiation. Cold Spring Harb. Symp. Quant Biol. 2011, 76, 247-255. [CrossRef] [PubMed]

6. Palatty, P.L.; Saldanha, E. Pharmacotherapy for Weight Management. J. Assoc. Phys. India 2012, 60, 34-40.

7. Chen, B.; Lam, K.S.; Wang, Y.; Wu, D.; Lam, M.C.; Shen, J.; Wong, L.; Hoo, R.L.; Zhang, J.; Xu, A. Hypoxia dysregulates the production of adiponectin and plasminogen activator inhibitor-1 independent of reactive oxygen species in adipocytes. Biochem. Biophys. Res. Commun. 2006, 341, 549-556. [CrossRef] [PubMed]

8. Charradi, K.; Elkahoui, S.; Limam, F.; Aouani, E. High-fat diet induced an oxidative stress in white adipose tissue and disturbed plasma transition metals in rat: prevention by grape seed and skin extract. J. Physiol. Sci. 2013, 63, 445-455. [CrossRef] [PubMed]

9. Cercato, L.M.; White, P.A.S.; Nampo, F.K.; Santos, M.R.V.; Camargo, E.A. A systematic review of medicinal plants used for weight loss in Brazil: Is there potential for obesity treatment? J. Ethnopharmacol. 2015, 176, 286-296. [CrossRef] [PubMed]

10. Fabri, R.L.; Nogueira, M.S.; Dutra, L.B.; Bouzada, M.L.M.; Scio, E. Antioxidant and antimicrobial potential of Asteraceae species. Braz. J. Med. Plants 2011, 13, 183-189.

11. Gene, R.M.; Cartana, C.; Adzet, T.; Marin, E.; Parella, T.; Canigueral, S. Antiinflammatory and analgesic activity of Baccharis trimera: Identification of its active constituents. Planta Med. 1996, 62, 232-235. [CrossRef] [PubMed]

12. Oliveira, A.C.; Endringer, D.C.; Amorim, L.A.; das Gracas, L.B.M.; Coelho, M.M. Effect of the extracts and fractions of Baccharis trimera and Syzygium cumini on glycaemia of diabetic and non-diabetic mice. J. Ethnopharmacol. 2005, 102, 465-469. [CrossRef] [PubMed]

13. Souza, S.P.; Pereira, L.L.S.; Souza, A.A.; Souza, R.V.; Santos, C.D. Study of antiobesity activity of methanolic extract of Baccharis trimera (Less.) DC. Braz. J. Pharm. 2012, 93, 27-32.

14. Souza, S.P.; Pereira, L.L.S.; Souza, A.A.; Santos, C.D. Inhibition of pancreatic lipase by extracts of Baccharis trimera (Less.) DC. Asteraceae: Evaluation of antinutrients and effect on glycosidases. Braz. J. Pharmacogn. 2011, 21, 450-455. [CrossRef]

15. Assaid, S.A.; Corrêa, A.D.; Chagas, P.M.B. Inhibition of digestive enzymes by medicinal plant aqueous extracts used to aid the treatment of obesity. J. Med. Plants Res. 2012, 6, 5826-5830.

16. Pires, C.A.S.; Queiroz, E.F.; Henriques, A.T.; Hostettmann, K. Isolation and On-line Identification of Antioxidant Compounds from Three Baccharis Species by HPLC-UV-MS/MS with Post-column Derivatisation. Phytochem. Anal. 2005, 16, 307-314. [CrossRef] 
17. Oliveira, S.Q.; Pizzol, F.D.; Moreira, J.C.F.; Schenkel, E.P.; Gosmann, G. Antioxidant activity of Baccharis spicata, Baccharis trimera and Baccharis usterii. Acta Farm. Bonaer. 2004, 23, 365-368.

18. Liu, G.S.; Chan, E.C.; Higuchi, M.; Dusting, G.J.; Jiang, F. Redox mechanisms in regulation of adipocyte differentiation: beyond a general stress response. Cells 2012, 1, 976-993. [CrossRef] [PubMed]

19. Oliveira, C.B.; Comunello, L.N.; Lunardelli, A.; Amaral, R.H.; Pires, M.G.S.; da Silva, G.L.; Manfredini, V.; Vargas, C.R.; Gnoatto, S.C.B.; de Oliveira, J.R.; et al. Phenolic Enriched Extract of Baccharis trimera Presents Anti-inflammatory and Antioxidant Activities. Molecules 2012, 17, 1113-1123. [CrossRef] [PubMed]

20. Sahreen, S.; Khan, M.R.; Khan, R.A. Evaluation of antioxidant activities of various solvent extracts of Carissa opaca fruits. Food Chem. 2010, 122, 1205-1211. [CrossRef]

21. McMurray, F.; Patten, D.A.; Harper, M.E. Reactive Oxygen Species and Oxidative Stress in Obesity-Recent Findings and Empirical Approaches. Obesity 2016, 24, 2301-2310. [CrossRef] [PubMed]

22. Vieira, T.O.; Seifriz, I.; Charão, C.C.T.; Oliveira, S.Q.; Creczynski-Pasa, T.B. Antioxidant effects of crude extracts from Baccharis species: Inhibition of myeloperoxidase activity, protection against lipid peroxidation, and action as oxidative species scavenger. Rev. Bras. Farmacogn. 2011, 21, 601-607. [CrossRef]

23. Soicke, H.; Leng-Peschlow, E. Characterisation of flavonoids from Baccharis trimera and their antihepatotoxic properties. Planta Med. 1987, 53, 37-39. [CrossRef] [PubMed]

24. Mira, L.; Fernandez, M.T.; Santos, M.; Rocha, R.; Florencio, M.H.; Jennings, K.R. Interactions of flavonoids with iron and cooper ions: a mechanism for their antioxidant activity. Free Radic. Res. 2002, 36, 1199-1208. [CrossRef] [PubMed]

25. ̌̉íha, M.; Karlíčková, J.; Filipský, T.; Macáková, K.; Rocha, L.; Bovicelli, P.; Silvestri, I.P.; Saso, L.; Jahodář, L.; Hrdina, R.; et al. In vitro evaluation of cooper-chelating properties of flavonoids. RSC Adv. 2014, 4, 32628-32638. [CrossRef]

26. Agyare, C.; Boakye, Y.D.; Bekoe, E.O.; Hensel, A.; Dapaah, S.O.; Appiah, T. Review: African medicinal plants with wound healing properties. J. Ethnopharmacol. 2016, 177, 85-100. [CrossRef] [PubMed]

27. Tinkov, A.A.; Polyakova, V.S.; Nikonorov, A.A. Chronic administration of iron and copper potentiates adipogenic effect of high fat diet in Wistar rats. Biometals 2013, 26, 447-463. [CrossRef] [PubMed]

28. Ristow, M.; Wolfrum, C. A radical opposition in body weight control. EMBO Mol. Med. 2013, 5, 1147-1148. [CrossRef] [PubMed]

29. Finelli, C.; Tarantino, G. What is the role of adiponectin in obesity related non-alcoholic fatty liver disease? World J. Gastroenterol. 2013, 19, 802-812. [CrossRef] [PubMed]

30. Liang, N.; Kitts, D. Role of Chlorogenic Acids in Controlling Oxidative and Inflammatory Stress Conditions. Nutrients 2016, 8, 16. [CrossRef] [PubMed]

31. Arçari, D.P.; Santos, J.C.; Gambero, A.; Ribeiro, M.L. The in vitro and in vivo effects of yerba mate (Ilex paraguariensis) extract on adipogenesis. Food Chem. 2013, 141, 809-815. [CrossRef] [PubMed]

32. Alves, M.G.C.F.; Almeida-Lima, J.; Paiva, A.A.O.; Leite, E.L.; Rocha, H.A.O. Extraction process optimization of sulfated galactan-rich fractions from Hypnea musciformis in order to obtain antioxidant, anticoagulant, or immunomodulatory polysaccharides. J. Appl. Phycol. 2015, 28, 1931-1942.

33. Melo, K.R.T.; Camara, R.B.; Queiroz, M.F.; Vidal, A.A.J.; Lima, C.R.M.; Melo-Silveira, R.F.; Almeida-Lima, J.; Rocha, H.A.O. Evaluation of sulfated polysaccharides from the brown seaweed Dictyopteris Justii as antioxidant agents and as inhibitors of the formation of calcium oxalate crystals. Molecules 2013, 18, 14543-14563. [CrossRef] [PubMed]

34. Melo-Silveira, R.F.; Fidelis, G.P.; Viana, R.L.S.; Soeiro, V.C.; Silva, R.A.S.; Machado, D.; Costa, L.S.; Ferreira, C.V.; Rocha, H.A.O. Antioxidant and Antiproliferative Activities of Methanolic Extract from a neglected agricultural product: Corn cobs. Molecules 2014, 19, 5360-5378. [CrossRef] [PubMed]

35. Nobre, L.T.B.; Vidal, A.A.J.; Almeida-Lima, J.; Oliveira, R.M.; Paredes-Gamero, E.J.; Medeiros, V.P.; Trindade, E.S.; Franco, C.R.C.; Nader, H.B.; Rocha, H.A.O. Fucan Effect on CHO Cell Proliferation and Migration. Carbohydr. Polym. 2013, 98, 224-232. [CrossRef] [PubMed]

Sample Availability: Samples of the extracts are available from the authors. 